reduction of deaths in that field. We hope to publish our findings in a similar way.-I am, etc.,

Pesearch Committee,
Loncion W.1.
$\begin{gathered}\text { Resitish Tuberculosis Association. } \\ \text { ReferencB }\end{gathered}$
$\begin{gathered}\text { Annual Report of the Chief Medical Officer of the } \\ \text { Ministry of Health, 1966, 1967. H.M.S.O. }\end{gathered}$

\section{Tongue Pain and Giant Cell Arteritis}

Sir,-Dr. A. H. Henderson (11 November, p. 337) draws attention to the importance of pain in the tongue as a feature in giant cell arteritis. We have found glossitis in $12.6 \%$ of a series of 87 cases of temporal arteritis. ${ }^{12}$ The glossitis varied from gangrene of the anterior two-thirds of the tongue to a sensation of burning. Commonly the tongue was raw-beef red and sore. There were also examples of blistering and bruising, and this, nogether with the pathogenesis of other skin lesions in giant cell arteritis, has led us to suppose that in vascular areas such as the tongue, scalp, and face necrosis is due to haemorrhage rather than occlusion."

We agree with Dr. Henderson that the tongue should be examined in every case where giant cell arteritis is suspected, as it may present important confirmatory evidence. -We are, etc.,

\section{P. D. C. Kinmont \\ D. I. McCallum.}

Derby.

REPERENCES

Kinmont, P. D. C., and McCallum, D. I., Brit. F. Derm. 1965, 77, 193.

: 二 Dermat. Digest, 1966, 5, No. 8, 51.

- - Brit. F. Derm., 1964, 76, 299.

\section{Cross-infection in a Surgical Unit}

SIR,-Dr. J. E. Tinne and others (11 November, p. 313) acknowledge that the addition of colistin to the routine post operative drip may be essential in combating the type of infection reported. They do, however, caution, ". . . its nephrotoxicity must be borne in mind."

To date no positive histopathological evidence has been offered to support the claim that colistin is nephrotoxic. The evidence from animal studies $^{1}$ is that when massive doses $(19.2 \mathrm{mg}$.) $\mathrm{kg}$ /day intraperitoneally) are given to rats and mice only very slight congestion with tubular necrosis can be detected; at levels of $9.6 \mathrm{mg} . /$ kg./day no such changes are seen. For such effects to appear in man, therefore, a dose of about $1,152 \mathrm{mg}$./day would be required, which is some $4 \frac{1}{2}$ times the recommended dose. In humans no histological evidence of damage was found in 11 renal biopsies ${ }^{2}$ following therapeutic doses of colistin, although Katz, ${ }^{4}$ using an excessive dose $(15.4 \mathrm{mg} . / \mathrm{kg} . /$ day), believed that in one patient nephrotoxicity was apparent, but the findings suggest that the lesion was regressing.

The question of nephrotoxicity must therefore be discussed in the light of reports of elevated blood urea nitrogen and plasma creatinine levels in patients receiving colistin for urinary infections ${ }^{5}$ or in healthy volunteers.' A fall in blood urea nitrogen during therapy has also been found, ${ }^{8}$ and the effect on renal function is clearly dose-dependent. ${ }^{3}$ ? Even so, doses of up to $720 \mathrm{mg}$./day have been used without affecting blood urea

nitrogen, ${ }^{10}$ and in conditions of elevated levels prior to therapy $(>50 \mathrm{mg} . / 100 \mathrm{ml}$.) no further change has been attributable to colistin. ${ }^{11}$ The reason for these variable transient and reversible changes in blood urea and creatinine in some cases is not clear. It has been suggested ${ }^{3}$ that colistin may be vasoactive, reducing renal blood flow and glomerular filtration rate, although this has been challenged ${ }^{4}$ on the basis of one case.

Clearly, so far as we are aware, no irreversible damage to the kidney has been demonstrated, and, whatever the significance of the observed blood changes, it is still held ${ }^{3}$ that the administration of colistin is of such therapeutic benefit as to allow its controlled use even where renal dysfunction is proved. As has rightly been pointed out by Dr. Tinne and his colleagues, there is an increasing hazard from Gram-negative infections in hospitals, especially due to $P s$. aeruginosa, which may be located in the sputum of staff members. A recent paper describes successful management of patients with positive sputum culture by combined intramuscular and aerosol colistin. This regimen resulted in therapeutically effective blood levels without involvement of the kidney.-We are, etc.,

P. A. P. PoMPA,
Medical Adviser.
A. D. S. CALDWELL,
Medical Information Officer.
$\begin{gathered}\text { Pharmax Limited, } \\ \text { Medical and Research Department, } \\ \text { Dartford, Kent. }\end{gathered}$

REPERENCES

' Wright, W. W., and Welch, H., Antibiot. Ann., Yow, E. M., Tan, E., Shane, L., Schonfeld, S., and Abu-Nassar, H., Arch., intern. Med., 196i, $108,664$.

- Fekety, F. R., Norman, P. S., and Cluff, L. B.,

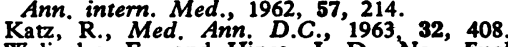

: Katz, R., Med. Ann. D.C., 1963 32, 408. Med., 1962, 266, 759 .

Med. 1962, 266, 759. Plorde, J. J., J. Amer.

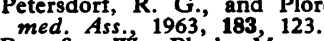

med. Ass., 1963, 183, 123 . Brit. F. Urol., 1966, 38, 495.

- Roberts, C. B., and Kirby, W. M. M., Anti-

- moss, S., Puig, J. R., and Zaremba, E. A., Antibiot. Ann., $1960,7,89$

Edgar, W. M., and Dickinson, K. M., Lancet, 1962, 2, 739.

McCabe, W. R., and Jackson, G. G., Amer. $Y$.

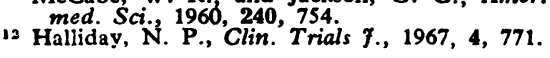

\title{
Which Stethoscope?
}

SIR,-On the basis that some $3 \%$ of adults are sufficiently hard of hearing to need hearing-aids there are several hundreds of general practitioners and others in this country for whom the article by Drs. C. S. Hampton and A. Chaloner (18 November, p. 388) is merely of academic interest, since they would hear practically nothing through even the most efficient stethoscope. Many

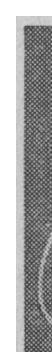


body to the psittacosis group of organisms in titres of $1 / 1024$ (3 October), 1/256 (12 October), and 1/64 (23 October). When the serological reports were received inquiry revealed that the patient had recently been in contact with budgerigars which were kept as domestic pets.

The history, the clinical picture, and the serological and post-mortem findings seem to warrant a diagnosis of psittacosis with cardiac and pulmonary signs. The persistent nausea and retching have not yet been explained. When further necropsy reports are available and the results of virus isolation studies have been completed we intend to publish a more detailed account of this case.-We are, etc.,

$$
\begin{aligned}
& \text { W. J. MACLENNAN. } \\
& \text { I. W. DYMOCR. } \\
& \text { Department of Materia Medica } \\
& \text { and Therapeutics. } \\
& \text { University of Glasgow } \\
& \text { and Stobhill General Hospital, } \\
& \text { Glasgow N.1. } \\
& \text { CoNstANCE A. C. Ross. } \\
& \text { Regional Virus Laboratory, } \\
& \text { Ruchill Hospital, } \\
& \text { Glaspow N.W. }
\end{aligned}
$$

\section{Deaths from Exposure}

SIR,-The annual winter toll of deaths from exposure begins this year with the loss of two African officer cadets on Dartmoor. ${ }^{1}$

Wide publicity has been given to the dangers of wet and cold by the mountaineering societies. ${ }^{2}$ The necessity of extra food and clothing, the importance of the early recognition of signs of fatigue, and the suicidal folly of travelling light appear to be widely known except perhaps in Army circles.

What is apparently not so well understood is that judgement is impaired by bad conditions before physical signs of exhaustion develop. Young men whose judgement has already been impaired by the necessity to show determination, drive, and enthusiasm, and who may in addition fear failing the course if they show prudence, are particularly likely to make wrong decisions. The inexperienced will tend to press on, and bring severe trouble upon themselves or other people.

Imperative instructions to abandon the operation in the event of deterioration of weather or the physical condition of the participants ought to be part of the briefing for this sort of training by ordeal. Without this it is likely to be unnecessarily costly. -I am, etc.

London S.B.27.

Frances Margaret Ulyatt.

\section{REPBRENCBS}

The Times, 3 and 4 November 1967 - Safety on Mountains, 1966, 6th ed. London.

Exposure, Notes on Recognition of Symptoms and
Treatment, 1964, Pamphlet 380 . London.

\section{Varicose Ulcers and Use of Topical Corticosteroids}

SIR,-I have read with great interest the letter on the above subject by Dr. C. D. Evans and others (25 November, p. 482).

As a general practitioner with considerable interest in dermatology I am well aware that current thinking certainly appears to suggest that the use of corticosteroid ointments, either with or without antibiotics, leads to the rapid extension of stasis or varicose ulcers. This point was particularly emphasized by Dr. R. P. Warin in his excellent article on "Advances in Treatment of Skin Diseases" in last October's Practitioner. ${ }^{1}$ Unfortunately this does not always seem to be borne out in practice from a general-practitioner point of view. I can think of numerous cases where the use of such an ointment has stimulated healing.

I am at present treating a case of a very large varicose ulcer of the right leg of some weeks' duration. In spite of the usual methods of treatment, including pressure bandaging, etc., this ulcer failed to heal, and eventually disintegrated into a dirty sloughing sore involving a large area in the lower third of the leg. As the patient refused to attend a dermatological clinic I eventually (in desperation) used an ointment containing oxytetracycline hydrochloride B.P. and hydrocortisone B.P. After one week there was dramatic improvement in the ulcer and after two weeks (two days ago) there was considerably more improvement, the ulcer now being half the size in width and depth, perfectly clean, with no evidence of secondary infection present.

If the use of corticosteroid increases the extension of the ulcer, one would expect to be confronted with a perfectly clean, dry lesion (due to the action of the antibiotic on secondary infection) but with a more penetrating ulcer due to the cortisone. Does the fact that this is not always so depend on the amount of time for which the corticosteroid has been applied or perhaps on some other factor like the $\mathrm{pH}$ of the lesion? Might there not be some synergistic action between steroid and antibiotic in certain cases? On the other hand, is this just a case of the dermatologist seeing only the general-practitioner failures and not their successes?

I should be grateful for your readers' views. -I am, etc.,

Glasgow S.3. Gerald M. JeSNER.

REPBRENCB

' Warin, R. P., Practitioner, 1967, 199, 446.

\section{Abortion and Conscience}

SiR,-Dr. Myre Sim (4 November, p. 297) exhorts those of us without religious objections to abortion to heed our medical consciences. $\mathrm{He}$ is so convinced of the rightness of his views that he brands any doctor who acts differently as lacking in conscience. I do not agree with this assumption. Many highly conscientious doctors favour abortion on social grounds. In the present state of knowledge it is still open to question whether in a particular family the addition of an unwanted child will endanger the health of the other children. We recognize the strong association which criminality and psychiatric disorder have with emotional and material deprivation in childhood, but these associations are not invariable nor can accurate predictions be made in the individual case. Many of us, while supporting Dr. Sim's call for more research, feel that available evidence is strong enough to warrant action.

The history of medicine abounds with instances where far-sighted action brought advances which, had they had to await incontestible evidence, would have been long delayed. John Snow removed the handle of the Broad Street pump 30 years before the cholera vibrio was isolated. For most of us it takes courage to recommend or to perform an abortion. It is an operation from which we shrink with a natural abhorrence. How much easier it is to do nothing, especially if inaction can be condoned by invoking "medical conscience." - I am, etc.,

London $\mathbb{W} .2$.

Alan Sanderson.

\section{Housing and Health}

SIR,-Wing-Commander D. M. Fanning (18 November, p. 382) in his masterly analysis of the effect of flat-dwelling on health draws attention to the increasing incidence of neurotic illness in flat-dwellers.

Is it not possible to lay this lamentable consequence fairly and squarely at the doors of the architects? It appalls me, on visiting patients who live in flats, to find perhaps $\mathbf{1 0 0}$ people living in one building, all in separate rooms with absolutely no common meetingground apart from the entrance hall. The appalling loneliness of flat-dwellers is accentuated many times over by the enforced juxtaposition of others in the same condition.

The provision of a common dining/sitting/ recreation-room where free-and-easy contacts could be encouraged would of course not solve the problem entirely. It would, however, be a step of the utmost importance from the point of view of psychological hygiene. It is time the medical profession insisted on such a provision in the construction of all future multi-storey flats.-I am, etc.,

\section{Huddersfield, S. L. HeNderson SMITH} Yorks.

\section{“ Big Spleen " Disease}

SIR,-In preliminary studies we have shown that in some patients with "big spleen" disease abnormal splenic uptake of ${ }^{59} \mathrm{Fe}$ in labelled red cells in vivo is reduced following antimalarial therapy. This effect was not seen in patients with hypersplenism due to other causes.

These early observations lend experimenta! support to the recommendation by Drs. E. J. Watson-Williams, N. C. Allan, and A. F. Fleming (18 November, p. 416) that antimalarial therapy should be given an extended trial in the treatment of suspected " big spleen" disease.-We are, etc.,

W. C. WATSON.

J. C. Ferguson.

J. Runcie.

Department of Medicine,
Nairobi Medical School.
Kenya.

\section{Carcinogenicity of Tobacco and Tobacco Smoke}

SIR,-Dr. H. P. Beckett's view (2 September, p. 614) that the carcinogenic factor(s) seems to be contained only in the smoke inhaled from the superheated area of the cigarette is, to say the least, doubtful.

Laboratory animals do not smoke, and it is the same yellow-brown condensate, tobacco tar, that stains the fingers of man that is painted on their skins. That carcinogens are present is therefore equally certain. As the available epidemiological and experimental data are not adequate to fix a safe dosage 